\title{
HIV infection and STD in drug addicted prostitutes in Amsterdam: potential for heterosexual HIV transmission
}

\author{
J A R van DEN HOEK, * H J A van HAASTRECHT, * B SCHEERINGA-TROOST, * \\ J GOUDSMIT, $\dagger$ R A COUTINHO* \\ From the ${ }^{*}$ Municipal Health Service, Department of Public Health and Environment, and the $\dagger$ Academic \\ Medical Centre, Department of Virology, University of Amsterdam, Amsterdam, The Netherlands
}

SUMMARY To assess the potential role of drug using prostitutes in the heterosexual transmission of human immunodeficiency virus (HIV), 117 prostitutes, recruited from December 1985 to November 1987 at a weekly evening sexually transmitted diseases (STD) clinic for drug using prostitutes only, were studied for the prevalence of HIV and STD. Intravenous drug use was reported by $96(82 \%)$ of the women. Antibody to HIV was found in 35/117 (30\%) women, all but one of whom had been using drugs intravenously. Most $(73,62 \%)$ of the prostitutes reported having had more than 2000 clients each in the preceding five years. In the six months preceding enrolment to the study they had practised mainly vaginal (106/117) and orogenital (82/117) intercourse; $90 \%(105 / 117)$ reported frequent use of condoms in vaginal intercourse and $65 \%(68 / 105)$ in orogenital intercourse. Despite frequent condom use, $81 \%(84 / 104)$ contracted one or more STD in this period. Considering the high incidence of HIV and STD and the finding by others that the presence of STD may facilitate transmission of HIV, we conclude that the potential for HIV transmission from these prostitutes to their clients (and vice versa) was clearly present.

In Africa, prostitutes are a main reservoir of sexually transmitted diseases (STD), ${ }^{1-4}$ and they are known to play an important part in the spread of the human immunodeficiency virus (HIV). ${ }^{5-7}$ The presence of STD, of which genital ulceration is probably the most important factor, ${ }^{8}$ (DW Cameron et al. International conference on AIDS, Washington 1987) may contribute to the transmission of HIV. ${ }^{5}$

In Amsterdam, prostitution is an economic necessity for many women addicted to drugs, in whom HIV infection is common. ${ }^{9}$ Addicted prostitutes are also known to play an important part in transmitting syphilis and other STD..$^{10}$ To assess the potential role of these prostitutes in the heterosexual transmission of HIV, we studied the variables of drug use, sexual practices, numbers of clients, the use of condoms, and the incidence of STD in the six months preceding testing for HIV as well as the prevalence of antibody to HIV.

Address for reprints: Dr R A Coutinho, Municipal Health Service, PO Box 20244, 1000 HE Amsterdam, The Netherlands

Accepted for publication 17 March 1989

\section{Patients and methods}

\section{STUDY POPULATION}

Women who had been using drugs and working as prostitutes for the past six months were recruited from December 1985 to November 1987 from attenders at a special STD clinic. This clinic was established in 1979 and is held weekly for addicted prostitutes only. ${ }^{.1}$ The staff of the clinic and of the different methadone programmes of the Municipal Health Service work closely together. Women prostitutes registered on a methadone programme are urged by their doctors or social workers to attend this clinic regularly. If they do not, methadone may be withheld and given in this clinic only after examination for STD. Addicted prostitutes not yet registered on methadone programmes (especially foreigners) may obtain methadone via this clinic at least while they are being treated for STD. Participation in the study was on a completely voluntary basis. After informed consent had been obtained, a specially trained nurse took a blood sample from and interviewed each participant, using a standard questionnaire that included questions concerning clinical symptoms, medical history 
(including STD), lifestyle, use of oral drugs, intravenous drug use, sexual practices, number of clients, and the use of condoms.

\section{SEROLOGICAL TESTS}

To detect antibody to HIV we used two enzyme linked immunosorbent assays (ELISAs). One was a direct binding assay using purified virus as antigen (Vironostika, Organon, Oss, The Netherlands), the other was a competitive ELISA using lysate of HIV infected cells as antigen (Wellcome anti HTLV-III, Wellcome, Dartford, England). ${ }^{12}$

The specificity for HIV was confirmed either by a competitive ELISA using DNA envelope and core proteins as antigen (Abbott HTLV-III confirmatory EIA, Abbott Laboratories, North Chicago, Illinois, United States of America) or by immunoblotting. ${ }^{13}$ We tested for hepatitis B surface antigen (HBsAg) using the Auszyme test, antibodies to HBsAg using the Ausab test, and antibodies to hepatitis $B$ core antigen (HBcAg) using the Corzyme test (all from Abbott Laboratories). As serological tests for syphilis we used the Treponema pallidum haemagglutination assay (TPHA) and, if that result was positive, the venereal disease research laboratory (VDRL) and the fluorescent treponemal antibody absorption (FTAABS) tests.

\section{EXAMINATION FOR STD}

We extracted from the medical records information about STD diagnosed in the six months preceding entry to the study. The period of six months was chosen as questions about sexual techniques and the use of condoms also related to that period.

Routine examination for STD in our clinic included: clinical examination of the skin and the anogenital region for skin eruptions, scabies, and pediculosis pubis; serological tests for syphilis; direct microscopy of Gram stained smears of material from the urethra and the cervix for gonorrhoea and of wet smears of material from the vagina for Trichomonas vaginalis, clue cells, and Candida albicans; cultures for Neisseria gonorrhoeae from the urethra, cervix, rectum, and throat; cultures for $T$ vaginalis and $C$ albicans if the results of microscopy were negative. Cultures for Chlamydia trachomatis were routinely taken every two months but more often if cervicitis was present. Cultures for herpes simplex virus and chancroid, and dark field examination for $T$ pallidum, were performed only when indicated. A positive culture was the diagnostic criterion for gonorrhoea, chlamydial infection, genital herpes, and chancroid. Trichomoniasis and vaginal candidiasis were diagnosed by microscopy or culture, and anaerobic vaginosis was diagnosed by microscopy only (clue cells). The diagnostic criterion for syphilis was positive results to serology (TPHA and TFA-ABS test) or showing $T$ pallidum by dark field examination.

STATISTICAL ANALYSIS

Association between HIV infection and (potential) risk factors was assessed univariately by the $\chi^{2}$ test, two tailed $t$ tests, and Kendall's rank correlation tests. $P$ values of less than 0.05 were defined as significant. Multivariate logistical regression was used to assess the extent of independent association between antibody to HIV and selected potential risk factors and coinfections.

By multiplying the reported number of clients a month with the reported proportion of sexual contacts for which no condoms were used, we calculated the number of clients practising unprotected sexual contact. Unprotected vaginal contacts were also calculated separately. These estimates were then log transformed to comply with the apparent logarithmic relation between the number of unprotected sexual contacts (total and vaginal only) and the number of STD diagnosed. Associations between the transformed estimates and the number of STD were examined using the product moment correlation statistic.

\section{Results}

CHARACTERISTICS OF THE PROSTITUTES (table 1)

Of 117 prostitutes participating in this study (mean age 27 (range 16-41) years) only 54 (46\%) had Dutch nationality. No difference in nationality and mean age was found between the study group and 300 women who attended the special STD clinic in 1986 and 1987. Most $(96 / 117,82 \%)$ of the prostitutes used drugs intravenously. A steady relationship with a man was mentioned by $63 \%(74 / 117)$ women, 50 of whom said that the relationship was of more than two years' duration. Of the 96 prostitutes with a history of intravenous drug use, 59 mentioned a steady male sexual partner and $29 / 59(49 \%)$ of these partners had never used drugs intravenously. The duration of prostitution was at least five years for $64 / 117(55 \%)$ prostitutes, two to five years for $29 / 117(25 \%)$, and less than two years for $24 / 117(20 \%)$.

Street prostitutes were the most common $(70 \%, 82 /$ $117)$ in our group, $9 \%(11 / 117)$ sat in windows to attract clients, $6 \%$ worked in clubs or bars, and $15 \%$ $(18 / 117)$ worked in another way, such as at home or at their clients' homes. The women had an average of 84 clients a month (SD 66; range 1-360) and $73(62 \%)$ reported having had more than 2000 customers in the preceding five years. Vaginal intercourse and orogenital contact were the techniques most often practised; $106 / 117(91 \%)$ practised vaginal intercourse and $82 /$ $117(70 \%)$ practised orogenital contact with at least 
Table 1 Selected characteristics of 117 prostitutes addicted to drugs in Amsterdam

\begin{tabular}{ll}
\hline & $\begin{array}{c}\text { No (\%) with } \\
\text { characteristic }\end{array}$ \\
\hline Nationality: & $54(46)$ \\
Dutch & $47(40)$ \\
West German & $16(14)$ \\
Other & $73(62)$ \\
In Amsterdam two years or more & $74(63)$ \\
Steady male sexual partner & $96(82)$ \\
Intravenous drug use & $64(55)$ \\
Prostitute for five years or more & $73(62)$ \\
More than 2000 clients in previous five years & \\
Treated for gonorrhoea once or more in & $75(64)$ \\
previous five years & \\
Treated for syphilis once or more in & $20(17)$ \\
previous five years & \\
Working place: & $82(70)$ \\
Street & $11(9)$ \\
Window & $7(6)$ \\
Ctub or bar & $18(15)$ \\
\hline
\end{tabular}

half their clients. Condom use in vaginal intercourse was reported as follows: always by $26 / 117(22 \%)$, more than two thirds of the time by $51 / 117(44 \%)$, about half the time by $28 / 117(24 \%)$, rarely (less than one third of the time) by $7 / 117(6 \%)$, and never by $5 / 117(4 \%)$. Orogenital contact was never practised by $12 / 117$ women; the remaining 105 reported condom use in orogenital contact as follows: $24 / 105(23 \%)$ always; $26 / 105(25 \%)$ more than two thirds of the time; $18 / 105(17 \%)$ about half the time; $27 / 105(26 \%)$ rarely; and $10 / 105(9 \%)$ never. In the preceding five years $75(64 \%)$ of the women said that they had been treated for gonorrhoea (once or more) and $20(17 \%)$ for syphilis.

\section{LABORATOR Y RESULTS}

On entry into the study (30\%) out of 117 addicted prostitutes had antibodies to HIV. All but one of them had been using drugs intravenously. Hepatitis B markers were tested for in 108 prostitutes and were present in $72(67 \%)$; 107 prostitutes were tested for syphilis and $21(20 \%)$ gave positive results in the TPHA and the FTA-ABS test.

\section{ASSOCIATION OF HIV INFECTION WITH \\ (POTENTIAL) RISK FACTORS AND OTHER INFECTIONS (tables 2 and 3).}

As all but one HIV infections were found in prostitutes with a history of intravenous drug use, we studied only those 96 prostitutes for an association between antibody to HIV and the variables in the questionnaire. No significant association was found between antibody to HIV and age, duration of stay in Amsterdam, or a more than two month stay outside The Netherlands in the preceding five years.

Significantly associated with antibodies to HIV were the drug use characteristics mentioned in table 2 and German nationality. Smoking heroin was associated with the absence of antibodies to HIV. The duration of prostitution and the number of clients in the previous five years were associated with antibody to HIV, as were a history of gonorrhoea, genital herpes, pneumonia, and swollen lymph nodes.

The variables associated with antibody to HIV mentioned in table 2 were multivariately analysed using stepwise logistical regression. Because the

Table 2 Univariate analysis of human immunodeficiency virus (HIV) infection in 96 female prostitutes with histories of intravenous drug use*

\begin{tabular}{|c|c|c|c|}
\hline & $\begin{array}{l}\text { No (\%) with } \\
\text { antibody to HIV } \\
(n=34)\end{array}$ & $\begin{array}{l}\text { No (\%) without } \\
\text { antibody to HIV } \\
(n=62)\end{array}$ & $P$ value $<$ \\
\hline $\begin{array}{l}\text { General characteristics: } \\
\text { West German ( } v \text { other nationalities) }\end{array}$ & $22(65)$ & $25(40)$ & 0.04 \\
\hline $\begin{array}{l}\text { Drug use characteristics: } \\
\text { Injected first more than five years ago } \dagger \\
\text { Injected drugs in past seven days } \dagger \\
\text { Borrowed used needles or syringes } 10 \text { times or more in past five years } \dagger \\
\text { Intravenous drug use daily during the past five years } \dagger \\
\text { Used methadone daily in past six months } \dagger \\
\text { Smoked heroin daily in past six months } \dagger\end{array}$ & $\begin{array}{l}27(79) \\
29(85) \\
17(50) \\
32(94) \\
28(82) \\
1(3)\end{array}$ & $\begin{array}{l}39(63) \\
43(69) \\
17(27) \\
48(77) \\
42(68) \\
12(19)\end{array}$ & $\begin{array}{l}0.03 \\
0.03 \\
0.02 \\
0.02 \\
0.05 \\
0.01\end{array}$ \\
\hline $\begin{array}{l}\text { Prostitution: } \\
\text { Started two years or more ago } \dagger \\
\text { More than } 2000 \text { sexual partners in past five years } \dagger \\
\text { Medical history: }\end{array}$ & $\begin{array}{l}31(91) \\
25(74)\end{array}$ & $\begin{array}{l}44(71) \\
34(55)\end{array}$ & $\begin{array}{l}0.02 \\
0.04\end{array}$ \\
\hline $\begin{array}{l}\text { Swollen lymph nodes in past six months } \ddagger \\
\text { Gonorrhoea once or more in past five years† } \\
\text { Genital herpes in past five years } \ddagger \\
\text { Pneumonia in past five years } \ddagger\end{array}$ & $\begin{array}{l}10(29) \\
28(82) \\
11(32) \\
10(29)\end{array}$ & $\begin{array}{l}1(2) \\
35(57) \\
4(6) \\
5(8)\end{array}$ & $\begin{array}{l}0.0002 \\
0.002 \\
0.003 \\
0.01\end{array}$ \\
\hline
\end{tabular}

*Variables measured on a dichotomous scaleł were tested using $\chi^{2}$. Variables measured on a multicategory ordinal scalet were arbitrarily dichotomised for presentation purposes here. Significance testing in those cases, however, was performed on the original data using Kendall's rank correlation test. 
Table 3 Multivariate logistical regression analyses of antibody to HIV in 96 prostitutes with histories of intravenous drug use

\begin{tabular}{|c|c|c|c|}
\hline Variable & Coefficient & $p$ value $<$ & $\begin{array}{l}\text { Odds ratio ( } 95 \% \\
\text { confidence interval) }\end{array}$ \\
\hline $\begin{array}{l}\text { Risk factors: } \\
\text { Recent intravenous drug use* } \\
\text { Duration of prostitution } \dagger \\
\text { Frequency of gonorrhoea } \ddagger\end{array}$ & $\begin{array}{l}0.38 \\
0.53 \\
0 \cdot 31\end{array}$ & $\begin{array}{l}0.006 \\
0.04 \\
0.02\end{array}$ & $\begin{array}{l}1.46(1.12-1.91) \\
1.70(1.05-2 \cdot 76) \\
1.37(1.06-1.76)\end{array}$ \\
\hline $\begin{array}{l}\text { Medical history: } \\
\text { Pneumonia in past five years§ } \\
\text { Swollen lymph nodes in past six months§ }\end{array}$ & $\begin{array}{l}1.44 \\
2.96\end{array}$ & $\begin{array}{l}0.03 \\
0.008\end{array}$ & $\begin{array}{c}4 \cdot 2(1 \cdot 2-14 \cdot 9) \\
19 \cdot 3(2 \cdot 2-167 \cdot 3)\end{array}$ \\
\hline
\end{tabular}

*Measured on a 7 point scale $(1=$ more than five years ago; 7 = today or yesterday).

†Measured on a 6 point scale $(1=$ last month; $6=$ more than five years ago).

† Measured on a 7 point scale $(0=$ none; $6=$ more than five times).

\$Measured dichotomously $(0=$ no, $1=$ yes $)$.

medical history variables were possibly consequences of HIV infection, instead of risk factors, they were analysed separately. Frequency of gonorrhoea (in the past five years), however, was also included in the general risk factor analysis. Table 3 shows the results of the two separate analyses. Recent intravenous drug use came out as the most significant variable associated with HIV.

Other variables that made a significant independent contribution to the prediction of antibody to HIV were the duration of prostitution and the frequency of gonorrhoea in the past five years. As far as the medical history analysis is concerned, swollen lymph nodes in the past six months and pneumonia in the past five years came out as significant independent variables associated with antibody to HIV.

\section{FREQUENCY OF STD}

According to the medical records of the special STD clinic, 104 women attended 281 consultation in the six months preceding their enrolment in the HIV study, which resulted in a mean incidence of consultations of 2.7 (range 1-14); 48 women were examined once, 21 twice, 13 three times, and 22 four times or more. Of the 117 women in this study, 13 were not examined in the six months before the intake.

During the 281 consultations the following STD were diagnosed in 84 of the 104 women: secondary syphilis (in 1), gonorrhoea (53; 29 once, 4 twice, 4 four times), cervical infection with $C$ trachomatis $(23 ; 21$ once, 1 twice), ulceration of unknown cause (11), primary genital herpes (3), recurrent genital herpes (3), trichomoniasis $(69 ; 38$ once, 12 twice, 2 three times or more), pediculosis pubis (21), and genital warts (newly diagnosed) (10). Symptomatic anaerobic vaginosis was diagnosed four times and vaginal candidiasis eight times. Only $20(19 \%)$ of the 104 women had no STD diagnosed during the six months before enrolment into the study.

To examine the validity of the self-reported number and type of sexual contacts as well as the reported use of condoms, we looked for an association between these variables and the number of STD diagnosed, assuming that the more unprotected sexual contacts one has the higher the prevalence of STD. Significant correlations were indeed found between the total number of diagnoses of STD and the estimated number of unprotected contacts $(\tau=0.38$; $p<0.0001$ ) and between the total number of vaginal and cervical diagnoses of STD (gonorrhoea, $C$ trachomatis infections, and trichomoniasis) and the estimated number of unprotected vaginal contacts $(\tau=0.24 ; p<0.008)$, which suggested a certain validity.

We also compared the prevalence of STD in HIV infected prostitutes with that in non-infected prostitutes. No differences were found in the mean number of consultations, the mean number of clients, or the mean numbers of STD a consultation between HIV infected and non-infected prostitutes.

\section{Discussion}

Although the addicted prostitutes reported practising mainly safe sex, $81 \%(84 / 104)$ of those examined clinically contracted one or more STD during the six months preceding the interview and HIV testing. The high frequencies of STD and the high prevalence of HIV infection may therefore make our group of addicted prostitutes comparable with prostitutes in Africa. In Nairobi, prostitutes are known for their role in transmitting HIV, and genital ulcerations are significantly associated with HIV infection in prostitutes and clients. ${ }^{6-8}$ The presence of genital ulcers in HIV infected prostitutes has been identified as a factor that increases HIV infectivity (DW Cameron $e t$ al. International Conference on AIDS, Washington 1987). An important difference between our group of prostitutes and African prostitutes is the incidence of chancroid, which is much more common in most of Africa than in Europe. Ulcerations caused by herpes simplex virus or with an unknown cause, however, did 
occur in our group of prostitutes, which may also have enhanced the chance of HIV transmission. ${ }^{14}$ We recently observed such transmission from a female prostitute with antibody to HIV to her non-drug-using steady male sexual partner after a period in which both had been suffering a recurrence of genital herpes. Other STD, such as syphilis (in men) and genital warts (in women), are also reported to be independently predictive of antibody to HIV. ${ }^{15}$ HIV p-17 antigen was shown recently in lymphocytes from the cervicovaginal secretions of infected women. ${ }^{16}$ This finding suggests that all kinds of STD may enhance the risk of heterosexual HIV transmission, as all genital infections increase the number of lymphocytes in the female genital tract.

Considering the prevalence of HIV infection and frequency of STD in our group of addicted prostitutes, we have to conclude that the potential for heterosexual HIV transmission was clearly present. An estimated 500-1000 addicted prostitutes work in Amsterdam. Most major cities in Europe as well as in the United States of America have addicted women working as prostitutes. STD programmes, particularly those established for addicted prostitutes only, are therefore of the utmost importance to prevent HIV transmission, as are campaigns to promote condom use in prostitutes and clients.

The prevalence of STD did not differ between the HIV infected and non-infected prostitutes. This argues against the increased susceptibility of prostitutes with antibody to HIV, as suggested elsewhere. ${ }^{3}$ The main risk factor for HIV infection in prostitutes remains intravenous drug use, as all but one HIV infected prostitutes had a history of intravenous drug use. Other independent risk factors associated with HIV were duration of prostitution and frequency of gonococcal infections in the previous five years. This finding suggests that heterosexual contact already plays a part in transmitting HIV to drug using prostitutes, either through clients or private sexual partners. The private sexual partners are often intravenous drug users themselves, and in Amsterdam a high percentage $(20 \%-30 \%)$ are infected with HIV. ${ }^{9}$ Transmission of HIV from these infected partners to the prostitutes may be facilitated by frequent occurrences of STD contracted during prostitution. In private sexual relations condoms are often not used. Health education directed to drug users should therefore contain information not only about safe drug use and safe sex with clients but also about the use of condoms in their private sexual relations.
We thank M Bakker for undertaking the blood tests and Y Hulst-Paardekooper for preparing the manuscript.

This study was supported by The Netherlands Foundation for Preventive Medicine (grant No 28-1258).

\section{References}

1 D'Costa LJ, Plummer FA, Bowner J, et al. Prostitutes are a major reservoir of sexually transmitted diseases in Nairobi, Kenya. Sex Transm Dis 1985;12:64-7.

2 Plorde DS. Sexually transmitted diseases in Ethiopia: social factors contributing to their spread and implications for developing countries. British Journal of Venereal Diseases 1981;57:357-62.

3 Plummer FA, D'Costa LJ, Nsanze H, Dylewski J, Karasira P, Ronald AR. Epidemiology of chancroid and Haemophilus ducreyi in Nairobi, Kenya. Lancet 1983;ii:1293-5.

4 Méheus A, De Clerq A, Prat R. Prevalence of gonorrhoea in a Central African town. British Journal of Venereal Diseases 1974;50:50-2.

5 Kreiss JK, Koech D, Plummer FA, et al. AIDS virus infection in Nairobi prostitutes: spread of the epidemic to East Africa. $N$ Engl J Med 1986;314:414-8.

6 van de Perre P, Clumeck N, Carael M, et al. Female prostitutes: a risk group for infection with human T-cell lymphotrophic virus type III. Lancet 1985;ii:524-7.

7 Clumeck N, van de Perre P, Carael M, Rouvroy D, Nzaramba D. Heterosexual promiscuity among African patients with AIDS. N Engl J Med 1985;313:182.

8 Greenblatt RM, Lukehart SA, Plummer FA, et al. Genital ulceration as a risk factor for human immunodeficiency virus infection. AIDS 1988;2:47-50.

9 van den Hoek JAR, Coutinho RA, van Haastrecht HJA, van Zadelhoff AW, Goudsmit J. Prevalence and risk factors of HIV infections among drug users and drug using prostitutes in Amsterdam. AIDS 1988;2:55-60.

10 van den Hoek JAR, Schoonhoven FJ, van Arnhem Q, Coutinho RA. Seksueel overdraagbare aandoeningen bij aan heroïne verslaafde prostitućes in Amsterdam, 1982. Ned Tijdschr Geneeskd 1984;128:272-4.

11 Coutinho RA, Schoonhoven FJ, van den Hoek JAR, Emsbroek JA. Influence of special surveillance programmes and AIDS on declining incidence of syphilis in Amsterdam. Genitourin Med 1987;63:210-3.

12 Reesink HW, Lelie PN, Huisman JG, et al. Evaluation of six enzyme immunoassays for antibody against human immunodeficiency virus. Lancet 1986;ii:483-6.

13 Lange JMA, Coutinho RA, Krone WJA, et al. Distinct IgG recognition pattern during the progression of subclinical and clinical infection with lymphadenopathy associated virus/ human T-cell lymphotropic virus. Br Med J 1986;292:228-30.

14 Holmberg SD, Stewart JA, Gerber AR, et al. Prior herpes simplex virus type 2 infection as a risk factor for HIV-infection. JAMA 1988;259:1048-50.

15 Quinn TC, Glasser D, Cannon RO, et al. Human immunodeficiency virus infection among patients attending clinics for sexually transmitted diseases. $N$ Engl $J$ Med 1988;318:197-203.

16 van de Perre P, De Clerq A, Cogniaux-Leclerc J, Nzaramba D, Butzler JP, Sprechen-Goldberger S. Detection of HIV p-17 antigen in lymphocytes but not epithelial cells from cervicovaginal secretions of women seropositive for HIV: implications for heterosexual transmission of the virus. Genitourin Med 1988;64:30-3. 